was a number of hyphal fusions between hyphæ of $P$. hirsutus and $P$. steinheilianus at the line of demarcation. Farther away from the line, monoearyon oidia in short chains like the fingers of the human hand were found due to haploidization of the binucleate hyphre of $P$. hirsutus, no clamp-connexions having occurred on the oidial hyphæ. In single (polysporous) culture of $P$. hirsutus, only monocaryon oidia were obtained, as noticed by Brodie in dicaryon mycelium of Collybia relutipes. So the presence of binucleate oidia in this case may be ascribed to the influence of pairing of $P$. steinheilianus on $P$. hirsutus.

For the observation of nuclei in oidia the agarfilms were fixed in Allen's bouin and stained with Haidenhain's iron-alum hæmatoxylin. Dicaryon oidia were cylindrical while monocaryon oidia were oval.

Botanical Laboratory,

Carmichael Medical College, Calcutta.

Aug. 3.

${ }^{1}$ Brodie, H. J., Amer. J. Bot., 23 (May 1936). 2 Vandendries, R., and Martens, P., Bull. Acad. Roy. Belgique, 8 (1932);

${ }^{3}$ Bose, S. R., La Cellule, 42 (1934).

\section{A Case of Club-Root of Swedes Due to a Seed-borne Infection}

Ceub-Root caused by Plasmodiophera brassica Wor. is one of the most serious diseases to which cultivated Brassicas are subject. The disease usually results from the planting of susceptible crops in contaminated soil, and the general assumption is that the infection is contracted from the soil. So far as I am aware, the relevant literature contains no record of an outbreak of the disease traceable to the use of contaminated seed. Three outbreaks of the disease which occurred in 1942 and 1943 in a Manchester garden could not, however, be traced as being due to a soil contamination. A survey of all attendant circumstances showed no previous Plasmodiophera history in the immediate locality or contributory circumstance by which it could have been introduced into the garden, and the evidence pointed to a seedborne infection.

As a small quantity of seed which had given rise to a diseased swede crop was available, experiments were carried out, designed to show, if possible, whether or not the disease had been seed-borne. If, in fact, the seed was infected, then a surface contamination with infected soil resulting from contact of the fruit with soil either before or during harvest was suspected, and the experiments were made with this possibility in mind. All sowings were made in boxes of compost and all the compost components and the containers were effectively sterilized. Fertilizers were added to the mixture as recommended for John Innes compost but no lime was added.

For each variety, one box was sown with untreated seed and one with seed 'surface sterilized' with hypochlorite. As controls, two boxes of Cambridge No. 5 Brussels sprouts were used. The Brussels sprouts seed had previously given disease-free plants. Two further boxes of Brussels sprouts were sown and immediately after sowing watered with swede seed washings obtained by soaking the swede seed in distilled water over-night.

Seed was sown on July 22. Germination was good in all boxes, and the seedlings grew satisfactorily. By mid-September some of the swedes had developed swellings at the bases of the hypocotyls and typical elubbed roots; in the cells of which numerous plasmodia of $P$. brassica were present. All the plants were harvested and minutely examined on October 1 , and the data obtained are assembled below :

\begin{tabular}{|c|c|c|}
\hline & $\begin{array}{l}\text { Total number } \\
\text { of plants }\end{array}$ & $\begin{array}{l}\text { Per cent } \\
\text { infected }\end{array}$ \\
\hline $\begin{array}{l}\text { Swede, var. Best-of-all } \\
\text { Untreated seed }\end{array}$ & 40 & $52 \cdot 5$ \\
\hline $\begin{array}{l}\text { Surface sterilized seed } \\
\text { Brussels sprout with Best-of-ail swede }\end{array}$ & 46 & $41 \cdot 3$ \\
\hline $\begin{array}{llll}\text { seed washings } & . & \ldots & \ldots\end{array}$ & 27 & 0 \\
\hline $\begin{array}{l}\text { Swede, var. Conqueror } \\
\text { Untreated seed .. }\end{array}$ & 45 & $15 \cdot 6$ \\
\hline $\begin{array}{l}\text { Surface sterilized seed } \ldots \\
\text { Bror }\end{array}$ & 63 & $1 \cdot 6$ \\
\hline $\begin{array}{l}\text { Brussels sprout with conqueror swede } \\
\text { seed washings }\end{array}$ & 30 & $16 \cdot 7$ \\
\hline $\begin{array}{l}\text { Brussels sprout } \\
\text { Untreated seed (1) }\end{array}$ & 42 & 0 \\
\hline Untreated seed (2) & 63 & 0 \\
\hline
\end{tabular}

The small amount of seed available precluded the carrying out of any more elaborate experiments, but the results obtained point clearly to the disease in the swedes being seed-borne. Further, the results obtained are entirely explicable if there is surface contamination of the seed; and surface sterilization of the seed with hypochlorite is no more, or not much more, effective in removing this than washing with water alone. Whereas the contamination of the Conqueror swedes is easily removable, that of the Best-of-all swedes is more adherent, with the result that while Conqueror seed washings cause infection of Brussels sprouts, the Best-of-all seed washings fail to do so. The conclusion that the disease is seed-borne and in one case at least (and probably in both) due to surface contamination appears inescapable.

Having established that club-root may appear in brassicas because of a seed-borne infection, some points of considerable importance are raised.

To determine what proportion of new outbreaks of the disease is in fact due to this cause is well-nigh impossible as so rarely is suspected seed available for experimental purposes. Nevertheless, even if the proportion is small and the risk of introducing the club-root organism into clean ground by this method remote, the development of suitable methods of seed sterilization may be worth while, while the importance of growing brassica seed crops only on clean land is clearly indicated.

I am indebted to Dr. H. J. Western for confirming my identification of $P$. brassica.

$$
\text { L. G. G. WARNE. }
$$

Botany Department, University, Manchester.

Oct. 7.

\section{A Speculation on the Nature of the Chemical Structure which is the Essence of the Malignant Cell}

Azthough it must be presumed that the chemical constitution of the cancer cell diverges in some subtle yet profound manner from the non-malignant, up to the present definite suggestions as to the manner of this difference have not been formulated in terms of atoms and molecules. Thus evidence for abnormal respiratory exchange has been adduced by many 